\title{
Suppression of Xanthomonas oryzae pv. oryzae biofilm formation by Acacia mangium methanol leaf extract
}

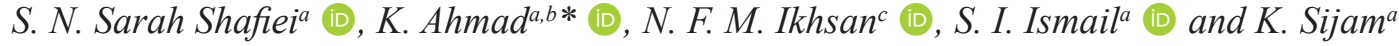 \\ ${ }^{a}$ Department of Plant Protection, Faculty of Agriculture, Universiti Putra Malaysia, Selangor, Malaysia \\ ${ }^{b}$ Institute of Plantation Studies - IKP, Universiti Putra Malaysia, Selangor, Malaysia \\ 'Department of Aquaculture, Faculty of Agriculture, Universiti Putra Malaysia, Selangor, Malaysia \\ *e-mail: khairulmazmi@upm.edu.my
}

Received: July 1, 2018 - Accepted: September 5, 2019 - Distributed: February 28, 2021

(With 2 figures)

\begin{abstract}
Xanthomonas oryzae pv. oryzae (Xoo), a pathogen responsible for rice bacterial leaf blight, produces biofilm to protect viable Xoo cells from antimicrobial agents. A study was conducted to determine the potency of Acacia mangium methanol (AMMH) leaf extract as a Xoo biofilm inhibitor. Four concentrations $(3.13,6.25,9.38$, and $12.5 \mathrm{mg} / \mathrm{mL}$ ) of AMMH leaf extract were tested for their ability to inhibit Xoo biofilm formation on a 96-well microtiter plate. The results showed that the negative controls had the highest O.D. values from other treatments, indicating the intense formation of biofilm. This was followed by the positive control (Streptomycin sulfate, $0.2 \mathrm{mg} / \mathrm{mL}$ ) and AMMH leaf extract at concentration $3.13 \mathrm{mg} / \mathrm{mL}$, which showed no significant differences in their O.D. values (1.96 and 1.57, respectively). All other treatments at concentrations of $6.25,9.38$, and $12.5 \mathrm{mg} / \mathrm{mL}$ showed no significant differences in their O.D. values $(0.91,0.79$, and 0.53 , respectively). For inhibition percentages, treatment with concentration $12.5 \mathrm{mg} / \mathrm{mL}$ gave the highest result (81.25\%) followed by treatment at concentrations 6.25 and $9.38 \mathrm{mg} / \mathrm{mL}$ that showed no significant differences in their inhibition percentage (67.75\% and $72.23 \%$, respectively). Concentration $3.13 \mathrm{mg} / \mathrm{mL}$ resulted in $44.49 \%$ of biofilm inhibition and the positive control resulted in $30.75 \%$ of biofilm inhibition. Confocal laser scanning microscopy (CLSM) analysis of Xoo biofilm inhibition and breakdown showed the presence of non-viable Xoo cells and changes in aggregation size due to increase in AMMH leaf extract concentration. Control slides showed the absence of Xoo dead cells.
\end{abstract}

Keywords: Xanthomonas oryzae pv. oryzae, Acacia mangium, biofilm formation, inhibition, breakdown.

\section{Supressão de Xanthomonas oryzae pv. oryzae: formação do biofilme oryzae pelo extrato de folhas de metanol de Acacia mangium}

\begin{abstract}
Resumo
Xanthomonas oryzae pv. oryzae (Xoo), um patogênico responsável pela influência bacteriana na folha do arroz, produz biofilme para proteger células Xoo viáveis de agentes antimicrobianos. Foi conduzido um estudo para determinar a potência do extrato de folha de Acacia mangium methanol (AMMH) como um inibidor de biofilme Xoo. Quatro concentrações $(3,13,6,25,9,38$ e 12,5 mg/mL) de extrato de folha de AMMH foram testadas quanto à sua capacidade de inibir a formação de biofilme Xoo em uma placa de microtitulação de 96 poços. Os resultados mostraram que os controles negativos tiveram o maior valor de OD do que os outros tratamentos, indicando a intensa formação de biofilme. Isso foi seguido do controle positivo (sulfato de estreptomicina, com concentração de $0,2 \mathrm{mg} / \mathrm{mL}$, e extrato de folha de AMMH, com concentração de $3,13 \mathrm{mg} / \mathrm{mL}$ ), que não apresentou diferenças significativas nos seus valores OD (1,96 e 1,57, respectivamente). Todos os outros tratamentos com concentrações de $6,25,9,38$, e $12,5 \mathrm{mg} / \mathrm{mL}$ não tiveram diferenças significativas nos seus valores OD $(0,91,0,79$, e 0,53 , respectivamente). Para percentagens de inibição, o tratamento com concentração $12,5 \mathrm{mg} / \mathrm{mL}$ apresentou o maior resultado $(81,25 \%)$, seguido do tratamento em concentrações de 6,25 e $9,38 \mathrm{mg} / \mathrm{mL}$, que não mostraram diferenças significativas na sua percentagem de inibição (67,75 e 72,23\%, respectivamente). Concentração $3,13 \mathrm{mg} / \mathrm{mL}$ resultou em $44,49 \%$ de inibição do biofilme, e o controle positivo resultou em $30,75 \%$ de inibição do biofilme. Análise por microscopia confocal de leitura a laser de inibição e separação de biofilme Xoo revelou a presença de células Xoo não viáveis e alterações no tamanho da agregação por causa do aumento na concentração de extrato de folha de AMMH. Slides de controle mostraram a ausência de células Xoo mortas.
\end{abstract}

Palavras-chave: Xanthomonas oryzae pv. oryzae, Acacia mangium, formação de biofilme, inibição, separação. 


\section{Introduction}

Xanthomonas oryzae pv. oryzae is a common bacterial pathogen accountable for rice leaf blight. The history of this pathogen began in Japan in 1884-1885 and later spread worldwide to other rice growing countries (Gnanamanickam et al., 1999). This pathogen enters the hydathodes or wounds, multiplies in the epitheme, and then moves along the xylem vessels where it begins to manifest the symptoms of blight disease on rice leaves (He et al., 2010). Like other plant bacterial pathogens, chemical communication is important for Xoo to induce biofilm formation and express its virulence traits. Thus, dissipating this mechanism of communication will enable the successful control of Xoo infection by reducing its virulence and pathogenicity (Singh et al., 2017).

Phytopathogens have evolved virulence factors that use diverse strategies to maintain survival in different environmental conditions and to successfully colonize and invade their hosts. Virulence factors are secreted in the extracellular environment of host cells. Biofilm is among the virulence factors in bacterial infection and is important for bacterial colonization and disease development. Biofilm is a matrix-enclosed bacterial population that adheres to each other with surfaces or interfaces (Costerton et al., 1995). Biofilm is known as a complex multilayer cellular structure that attaches to inanimate surfaces or tissues and that is embedded within an exopolysaccharide material (Kjelleberg and Molin, 2002; Dow et al., 2003).

Biofilms provide the predominant space for bacterial species to live in artificial and natural environments. The dynamic structures of biofilm amidst planktonic and biofilm modes of growth usually form in response to different environmental signals (Sutherland, 2001). The ability of phytopathogenic bacteria to form and separate from biofilms is an important indicator for durability on leaf surfaces and inside host plants. Infections spread throughout a plant and then complete the disease cycle (Crossman and Dow, 2004). Bacteria living in biofilms differ in their physiology from free-living cells. Biofilms supply limited nutrients for bacteria, which promotes the exchange of genetic material and increases diversity (Boles et al., 2004). Bacterial cells that predominantly live within biofilms are generally more resistant to antibiotics, host defense responses, and environmental stresses than planktonic bacteria (Rigano et al., 2007).

Various bacterial and fungal infections can be controlled by inhibiting biofilm formation. An alternative to block biofilm formation is the use of plant extracts and active compounds (Lizana et al., 2013; Sanchez et al., 2016). Plants are living organisms that generate hundreds or even thousands of secondary metabolites proven to possess antimicrobial properties against a wide range of pathogens. Plant extracts are gaining popularity among scientists worldwide as they are typically safe, biodegradable, environmentally friendly, and can provide myriad organic chemical compounds that can be used and tested against pathogens that trigger infection in humans, animals, and plants.
Acacia is a cosmopolitan genus that comprises 1,200-1,300 species that can be found in the three subgenera of Acacia, Aculeiferum, and Phyllodinae (Maslin, 1995). This plant belongs to the pea family Fabaceae, with subfamily Mimosoideae. Acacia mangium Willd, or brown salwood, is the most common Acacia species. These are found growing in plantations in Peninsular and East Malaysia. In Malaysia, the common name for this tree is Sabah salwood or mangium. It is native to Australia, Papua New Guinea, and Indonesia and known as a fast-growing species. This tree receives special consideration in forest plantations due to its exceptional growth, reproducibility, and adaptability to grow on degraded land (Ajik, 2002).

However, uses of $A$. mangium for purposes other than wood products and timbers have not been extensively explored, including its potency as an antimicrobial agent against other plant pathogens. This tree is typically harvested for wood while other major parts, such as leaves, are left to sun-dry and are burned. This study, therefore, was conducted to determine the ability of Acacia mangium methanol leaf extract to inhibit Xanthomonas oryzae pv. oryzae biofilm formation, which is among the important virulence factors in bacterial infection.

\section{Materials and Methods}

\subsection{Inhibition of Xoo biofilm formation by AMMH leaf extract}

The inhibition of Xoo biofilm was conducted using 96-well flat-bottomed microtiter plates. Four different concentrations $(12.5,9.38,6.25$, and $3.13 \mathrm{mg} / \mathrm{mL})$ of extract were prepared in sterile Mueller Hinton broth (MHB). Each broth with its respective concentration of A. mangium methanol (AMMH) leaf extract was pipetted into a microtiter plate. The negative control well contained only sterile MHB while the positive control well contained a mixture of streptomycin sulphate with MHB that yielded concentration $0.2 \mathrm{mg} / \mathrm{mL}$ (Antunes et al., 2010).

A $50 \mu \mathrm{L}$ aliquot of standardized Xoo suspension was pipetted into each well containing test solutions, including the negative and positive control wells. The microtiter plate was covered with a lid and incubated at $30^{\circ} \mathrm{C}$ for two days. After incubation, the well contents were decanted gently by tapping. Wells were washed twice with sterile phosphate buffer solution (PBS) and left to dry under laminar flow for 30 minutes. After the wells were dry, they were stained with Crystal Violet (CV) and left for 30 minutes. Later, the $\mathrm{CV}$ was decanted and the wells washed several times with sterile distilled water to remove CV residues from the plates. A $150 \mu \mathrm{L}$ aliquot of $95 \%$ ethanol was pipetted into test wells and incubated for 30 minutes (Aka and Haji, 2015).

The optical density of well contents was determined using a Multiskan Go UV Spectrophotometer set at $570 \mathrm{~nm}$. Biofilm inhibition was calculated using a formula (Equation 1) suggested by Marino et al. (2010): 
$1-\left[\frac{\text { O.D. }_{570} \text { Treated with extract }}{\text { O.D. } 570 \text { Negative control }}\right] \times 100$

The results were analyzed using SAS 9.4 software (SAS Institute, 2013) to compare the means of inhibition between concentrations and controls.

\subsection{Confocal laser scanning microscopy analysis on biofilm inhibition and breakdown structure}

The effect of AMMH leaf extract against Xoo biofilm was measured on a glass microscope slides. To study the effect of AMMH leaf extract against Xoo biofilm inhibition, four Falcon tubes with total volumes of $35 \mathrm{~mL}$ of MHB with different extract concentration mixture was prepared to obtain final concentrations of $3.13,6.25,9.38$, and $12.5 \mathrm{mg} / \mathrm{mL}$ alongside the glass microscope slides within the tubes. A $100 \mu \mathrm{L}$ aliquot of standardized Xoo suspension was pipetted into each Falcon tube. The control tube contained only MHB and Xoo suspension. The control tube and Falcon tubes along with the test materials were incubated for 48 hours at $30^{\circ} \mathrm{C}$ (Pratiwi et al., 2015).

To examine the breakdown of biofilm formation, $500 \mu \mathrm{L}$ of Xoo suspension was dispersed onto glass microscope slides that were then placed in glass Petri dishes and incubated at $30^{\circ} \mathrm{C}$ for 48 hours without any disturbance. Then, the glass slides were taken out and washed gently with sterile PBS before being placed into four Falcon tubes with different concentrations of AMMH leaf extract and the control tubes. The tubes were then incubated for 48 hours at $30^{\circ} \mathrm{C}$ (Pratiwi et al., 2015).

After incubation, all glass slides for both assays were removed from the broth mixture and washed gently with PBS. The glass slides were air dried under laminar flow for 15 minutes to remove excess PBS. A LIVE/DEAD BacLight (L7012) bacterial viability kit (Thermo Fisher Scientific) containing component A, SYSTO 9 dye (3.34 mM), and component B, propidium iodide $(20 \mathrm{mM})$, was prepared with a 1:1 ratio according to the manufacturer's instructions. A $3 \mu \mathrm{L}$ aliquot of LIVE/DEAD stain was mixed into $1 \mathrm{~mL}$ of distilled water and vortexed to ensure the solutions were well mixed. The dried glass slides were stained with $200 \mu \mathrm{L}$ of the LIVE/DEAD stain and covered with glass cover slips. The glass cover slips were sealed with transparent nail polish and then incubated in the dark for 30 minutes. The stained glass slides were viewed on the same day using the CLSM unit at the Microscopy Unit, Institute of Bioscience, UPM. During the staining process, the stain and stained samples were protected against light to ensure the viability of the stain.

\section{Results and Discussion}

\subsection{Inhibition of Xoo biofilm formation by AMMH leaf extract}

AMMH leaf extract at concentrations ranging from 3.13 to $12.5 \mathrm{mg} / \mathrm{mL}$ exhibited different optical density values represented by $X o o$ biofilm formation and inhibition percentage of Xoo biofilm. Table 1 shows that the control (broth containing untreated Xoo cells) had the highest mean of optical density value of 2.83 followed by treatment with streptomycin sulphate (1.96) at a concentration of $0.2 \mathrm{mg} / \mathrm{mL}$, which showed no significance difference with treatment using AMMH leaf extract (1.57) at a concentration of $3.13 \mathrm{mg} / \mathrm{mL}$. The number of Xoo cells was reduced after exposure to increasing concentrations of AMMH leaf extract of $6.25,9.38$, and $12.5 \mathrm{mg} / \mathrm{mL}$, corresponding to optical density (O.D.) values of 0.91 , 0.79 , and 0.53 , respectively (Table 1 ).

Inhibition percentage showed that AMMH leaf extract at a concentration of $12.5 \mathrm{mg} / \mathrm{mL}$ possessed the highest inhibition at $81.25 \%$. The $X o o$ biofilm inhibition reduced when the concentration of AMMH leaf extract was reduced. Concentrations of 6.25 and $9.38 \mathrm{mg} / \mathrm{mL}$ showed no significant differences with $X o o$ biofilm inhibition percentages of $67.75 \%$ and $72.23 \%$, respectively. The Xoo biofilm inhibition by streptomycin sulphate showed the lowest inhibition percentage of $30.75 \%$. The inhibition of Xoo biofilm showed significant differences among treatments.

The decrement in absorbance value for different treatments showed that biofilm formation was reduced laterally after exposure to higher AMMH leaf extract concentrations. Both controls (broth and streptomycin) contained greater numbers of Xoo cells and gave higher optical density (O.D.) values compared with Xoo cells treated with AMMH leaf extract.

In vitro success in controlling Xoo biofilm formation by AMMH leaf extract may be an important key for controlling Xoo in-vivo. In 2014, a study on inhibition of $X$. citri biofilm formation using D-leucine and 3-indolylacetonitrile in vitro provided useful information in controlling $X$. citri in the glasshouse (Li and Wang, 2014). Based on the in-vitro results, they tested the ability of these compounds to inhibit $X$. citri biofilm in the glasshouse using foliar-applied biofilm inhibitors to control canker on citrus.

To date, there has been no scientific publication on the antibiofilm activity of plant extracts against Xanthomonas. Most of the studies used pure organic compounds such as monoacylglycerols, 2-(methylsulfonyl)-5-(4-fluorophenyl)-1, 3, 4-oxadiazole, cis-2-decenoic acid, and $\beta$-mannanase to determine antibiofilm activity against genus Xanthomonas

Table 1. Biofilm formation and inhibition percentage of Xanthomonas oryzae pv. Oryzae.

\begin{tabular}{|c|c|c|c|c|c|c|}
\hline \multirow{2}{*}{ Parameters } & \multicolumn{2}{|c|}{ Controls } & \multicolumn{4}{|c|}{ AMMH Leaf Extract (mg/mL) } \\
\hline & Negative & Positive & 3.13 & 6.25 & 9.38 & 12.5 \\
\hline O.D. ${ }_{570}$ & $2.83 \pm 1.06^{\mathrm{c}}$ & $1.96 \pm 0.22^{b}$ & $1.57 \pm 0.17^{\mathrm{b}}$ & $0.91 \pm 0.08^{\mathrm{a}}$ & $0.79 \pm 0.09^{\mathrm{a}}$ & $0.53 \pm 0.05^{\mathrm{a}}$ \\
\hline Inhibition \% & - & $30.75^{\mathrm{a}}$ & $44.49^{\mathrm{b}}$ & $67.75^{\mathrm{c}}$ & $72.23^{\mathrm{c}}$ & $81.25^{\mathrm{d}}$ \\
\hline
\end{tabular}

Note: Means were compared among the treatments for each parameter with $N=9(p<0.05)$. Means with the same letters indicate no significance difference among the treatments. 
(Dow et al., 2003; Marques et al., 2015; Shi et al., 2015; Ham and Kim, 2016).

\subsection{Confocal laser scanning microscopy observation of biofilm inhibition and breakdown}

Confocal laser scanning microscopy analysis on biofilm inhibition and breakdown showed clearly the conditions of Xoo biofilm after being treated with AMMH leaf extract compared with the control. The Xoo dead cells increased when the concentration of AMMH leaf extract increased. The control showed no visible dead cells after staining with LIVE/DEAD stain. The aggregation size of biofilm was more compact when treated with the lower AMMH leaf extract concentration of $3.13 \mathrm{mg} / \mathrm{mL}$. The biofilm aggregation began to separate at a concentration of $6.25 \mathrm{mg} / \mathrm{mL}$ and completely diminished at a concentration of $12.5 \mathrm{mg} / \mathrm{mL}$ (Figures 1 and 2).

Based on the CLSM observation, both assays showed distinct effects when treated with AMMH leaf extract. Biofilm inhibition by AMMH leaf extract at a concentration of $3.13 \mathrm{mg} / \mathrm{mL}$ showed the presence of more dead cells compared with the breakdown assay. In the breakdown assay, the absence of Xoo dead cells was nearly the same as in the control. Even though the aggregation sizes for both
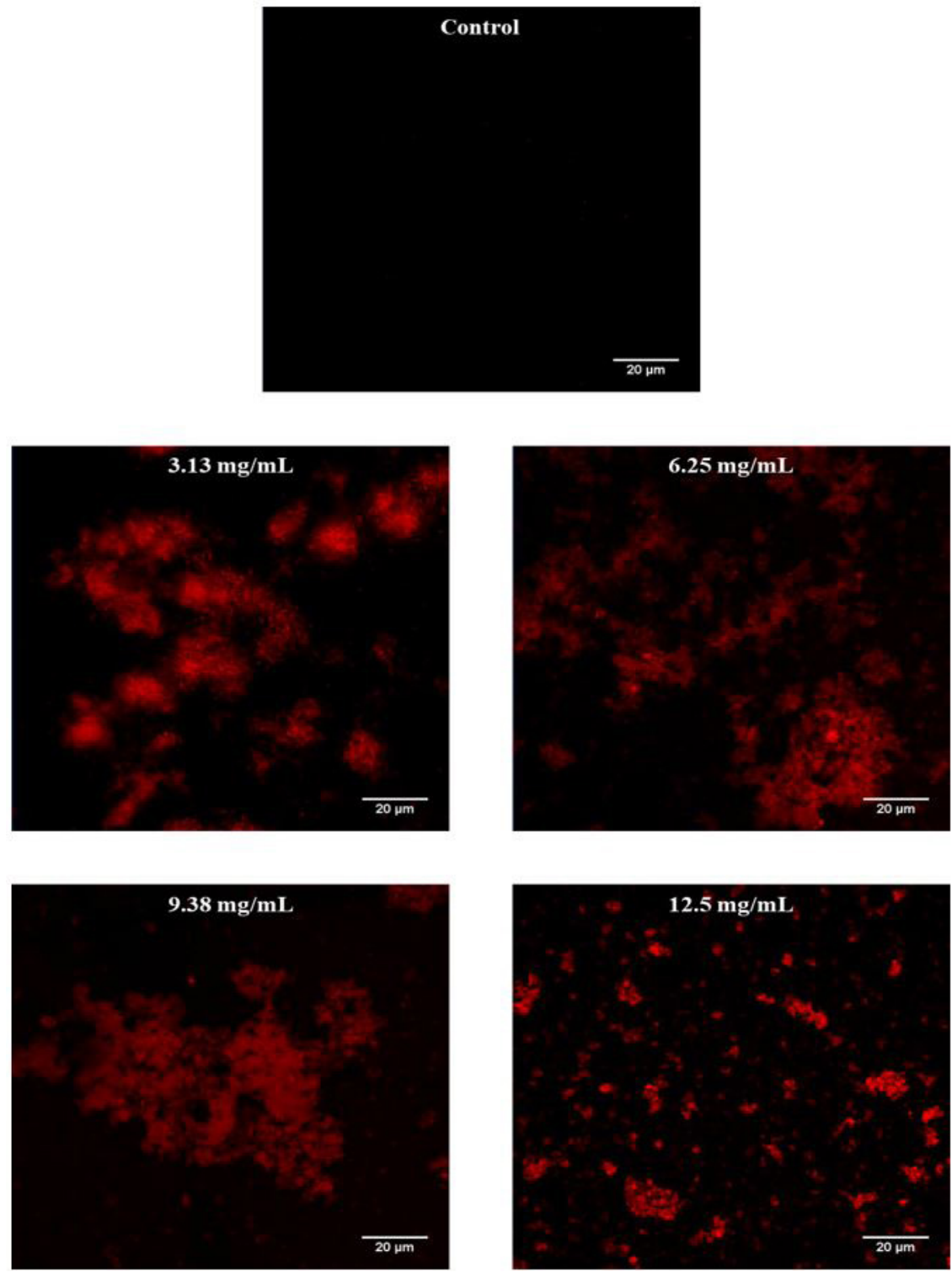

Figure 1. Confocal laser scanning microscopy images of $X$. oryzae pv. oryzae biofilm inhibition by AMMH leaf extract. The Xoo biofilm was easily inhibited at various concentrations of AMMH leaf extract. There were visible dead bacterial cells present in the AMMH 3.13, 6.25, 9.38, and $12.5 \mathrm{mg} / \mathrm{mL}$ images. Dead cells were represented by red coloration when stained with LIVE/DEAD BacLight. Control showed the absence of dead bacterial cells. CLSM imaging was conducted after 48 hours of incubation and under magnification 1 x 63 with scale bar $20 \mu \mathrm{m}$. 

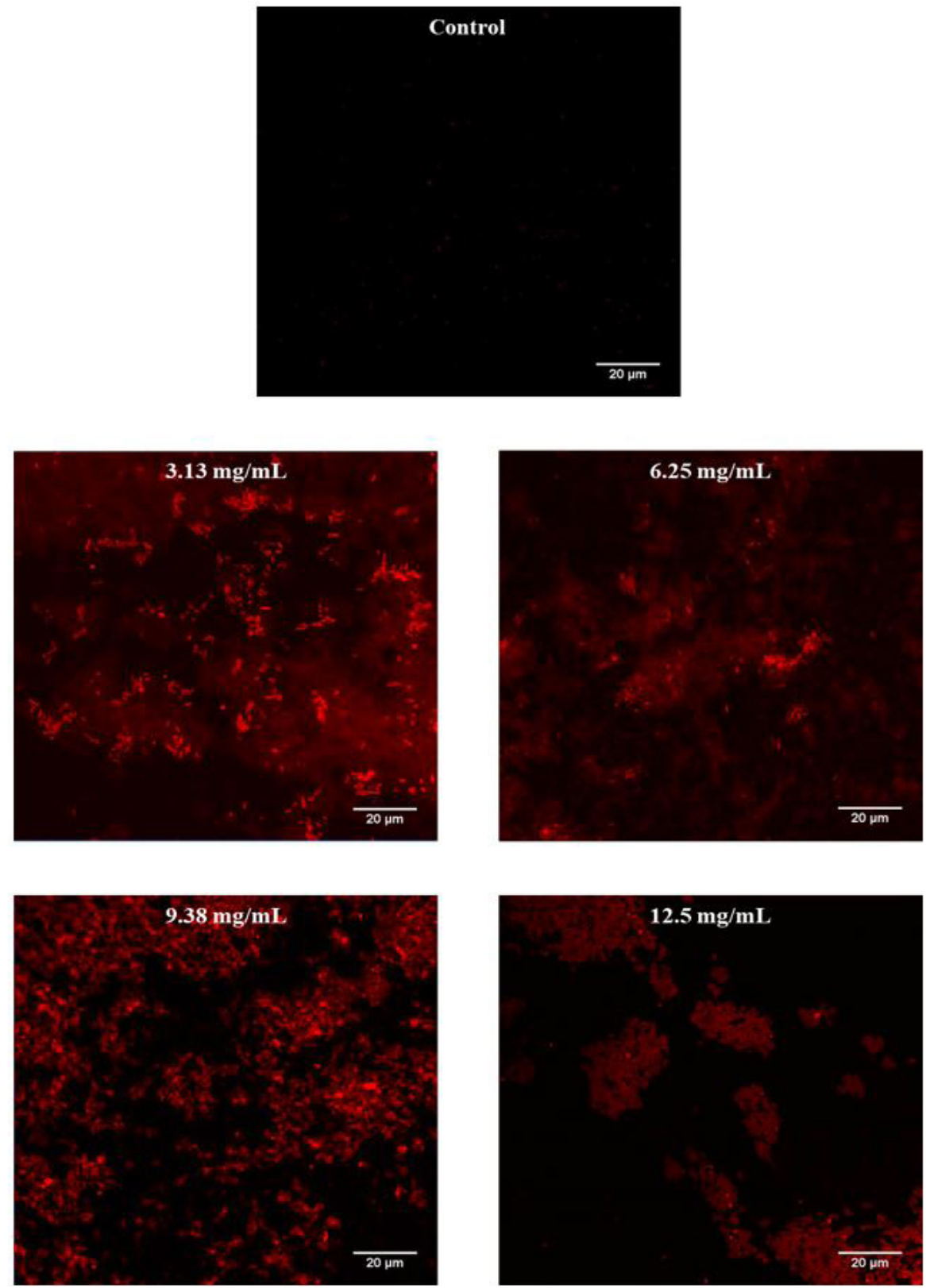

Figure 2. Confocal laser scanning microscopy images of $X$. oryzae pv. oryzae biofilm breakdown by AMMH leaf extract. There were fewer dead cells in the AMMH 3.13 and $6.25 \mathrm{mg} / \mathrm{mL}$ images, showing that biofilm breakdown requires higher AMMH leaf extract concentrations. The massive Xoo dead cells were only observed in images for AMMH 9.38 and $12.5 \mathrm{mg} / \mathrm{mL}$ concentrations. CLSM imaging was conducted after 48 hours of incubation and under magnification 1 x 63 with scale bar $20 \mu \mathrm{m}$.

assays were reduced when the concentration of AMMH leaf extract was increased, the breakdown assay still showed the presence of cell aggregation at the higher concentration of $12.5 \mathrm{mg} / \mathrm{mL}$ compared with the inhibition assay.

Differences in the visual results of both assays are in agreement with previous findings (Lou, 2010), which state that the breakdown of biofilm using antibacterial agents has become quite challenging. This situation has been related to solid formation and attachment of the biofilm itself to the surface. Differing from inhibition activity, the antibacterial compounds act as preventative agents by killing and interrupting the ability of the bacterial cell to attach and form the biofilm.

In both assays, increased extract concentration caused a loss of aggregate structures and reduced cell density compared with the control, in which the cells tended to form clusters due to live cells embedded in the polysaccharide matrix (Pratiwi et al., 2015). The dead cells in both assays 
tended to be present within the colonies portion and are surrounded by an outer layer of live cells. Previous research had related the presence of active compounds within plant extracts interacting with the expression genes that contribute to initial attachment, facilitating the reduction of biofilm formation (Dineshbabu et al., 2015).

The presence of plant extracts in the growth medium for biofilm created unfavorable conditions for biofilm attachment. Biofilm attachment requires organic and inorganic molecules as well as nutrients for surface conditioning. A lack of nutrients will cause the bacterial cells within the biofilm to revert to planktonic state. Later, the bacterial cells will become unattached and float freely when treated with leaf extract (Lou, 2010). Surface conditioning enhances cell growth and provides the most suitable and stable conditions for cell attachment, hence promoting the cells' adherence to the surface and leading to infection (Sandasi et al., 2010).

\section{Acknowledgements}

Author(s) would like to thank the Ministry of Higher Education (MOHE) for providing financial assistance under FRGS (FRGS/1/2014/STWN03/UPM/02/4) research scheme to conduct the research at Universiti Putra Malaysia. We also thank Dr. Erneeza Mohd Hata from the Bacteriology Laboratory, Universiti Putra Malaysia, for providing the pure culture of Xanthomonas oryzae pv. oryzae.

\section{References}

AJIK, M., 2002. Acacia species planting trial at Segaliud Lokan, Sandakan, Sabah, Malaysia. Journal of Tropical Forest Science, vol. 14, no. 3, pp. 421-424.

AKA, S.T. and HAJI, S.H., 2015. Sub-MIC of antibiotics induced biofilm formation of Pseudomonas aeruginosa in the presence of chlorhexidine. Brazilian Journal of Microbiology, vol. 46, no. 1, pp. 149-154. http://dx.doi.org/10.1590/S1517-838246120140218. PMid:26221101.

ANTUNES, A.L.S., TRENTIN, D.S., BONFANTI, J.W., PINTO, C.C., PEREZ, L.R., MACEDO, A.J. and BARTH, A.L., 2010. Application of a feasible method for determination of biofilm antimicrobial susceptibility in staphylococci. Acta Pathologica, Microbiologica, et Immunologica Scandinavica, vol. 118, no. 11, pp. 873-877. http://dx.doi.org/10.1111/j.1600-0463.2010.02681.x. PMid:20955460.

BOLES, B.R., THOENDEL, M. and SINGH, P.K., 2004. Self-generated diversity produces "insurance effects" in biofilm communities. Proceedings of the National Academy of Sciences of the United States of America, vol. 101, no. 47, pp. 16630-16635. http://dx.doi.org/10.1073/pnas.0407460101. PMid:15546998.

COSTERTON, J.W., LEWANDOWSKI, Z., CALDWELL, D.E., KORBER, D.R. and LAPPIN-SCOTT, H.M., 1995. Microbial biofilms. Annual Review of Microbiology, vol. 49, no. 1, pp. 711745. http://dx.doi.org/10.1146/annurev.mi.49.100195.003431. PMid:8561477.

CROSSMAN, L. and DOW, J.M., 2004. Biofilm formation and dispersal in Xanthomonas campestris. Microbes and
Infection, vol. 6, no. 6, pp. 623-629. http://dx.doi.org/10.1016/j. micinf.2004.01.013. PMid:15158198.

DINESHBABU, J., DARSINI, D.T.P., SRINIVASAN, P., EVERLYNE, I.M. and MANIMEKALAI, K., 2015. Synergistic anti-biofilm activity of medicinal plants against biofilm forming Streptococcus pyogenes from pharyngitis patients. Indo American Journal of Pharmaceutical Research, vol. 5, no. 8, pp. 2598-2606.

DOW, J.M., CROSSMAN, L., FINDLAY, K., HE, Y.Q., FENG, J.X. and TANG, J.L., 2003. Biofilm dispersal in Xanthomonas campestris is controlled by cell-cell signaling and is required for full virulence to plants. Proceedings of the National Academy of Sciences of the United States of America, vol. 100, no. 19, pp. 10995-11000. http://dx.doi.org/10.1073/pnas.1833360100. PMid:12960398.

GNANAMANICKAM, S.S., PRIYADARISINI, V.B., NARAYANAN, N.N., VASUDEVAN, P. and KAVITHA, S., 1999. An overview of bacterial blight disease of rice and strategies for its management. Current Science, vol. 77, no. 11, pp. 1435-1443.

HAM, Y. and KIM, T.J., 2016. Inhibitory activity of monoacylglycerols on biofilm formation in Aeromonas hydrophila, Streptococcus mutans, Xanthomonas oryzae and Yersinia enterocolitica. SpringerPlus, vol. 5, no. 1, pp. 1526. http://dx.doi.org/10.1186/ s40064-016-3182-5. PMid:27652099.

HE, Y.W., WU, J., CHA, J.S. and ZHANG, L.H., 2010. Rice bacterial blight pathogen Xanthomonas oryzae pv. oryzae produces multiple DSF-family signals in regulation of virulence factor production. BMC Microbiology, vol. 10, no. 1, pp. 187. http:// dx.doi.org/10.1186/1471-2180-10-187. PMid:20615263.

KJELLEBERG, S. and MOLIN, S., 2002. Is there a role for quorum sensing signals in bacterial biofilms? Current Opinion in Microbiology, vol. 5, no. 3, pp. 254-258. http://dx.doi.org/10.1016/ S1369-5274(02)00325-9. PMid:12057678.

LI, J. and WANG, N., 2014. Foliar application of biofilm formation-inhibiting compounds enhances control of citrus canker caused by Xanthomonas citri subsp. citri. Phytopathology, vol. 104, no. 2, pp. 134-142. http://dx.doi.org/10.1094/PHYTO-0413-0100-R. PMid:23901828.

LIZANA, J.A., LOPEZ, S., MARCHAL, A., SERRANO, U., VELASCO, D. and ESPINOSA-URGEL, M., 2013. Use of plant extracts to block bacterial biofilm formation. In: High School Students for Agricultural Science Research: Proceedings of the 3rd Congress PIIISA, 2013, Granada. España: CSIC, pp. 43-50.

LOU, K.J., 2010. [viewed 8 December 2017]. Triggering biofilm breakdown. Science-Business Exchange [online], vol. 3, no. 19, pp. 576-576. Available from: https://www.nature.com/scibx/ journal/v3/n19/full/scibx.2010.576.html

MARINO, A., BELLINGHIERI, V., NOSTRO, A., MICELI, N., TAVIANO, M.F., GÜVENÇ, A. and BISIGNANO, G., 2010. In vitro effect of branch extracts of Juniperus species from Turkey on Staphylococcus aureus biofilm. FEMS Immunology and Medical Microbiology, vol. 59, no. 3, pp. 470-476. http:// dx.doi.org/10.1111/j.1574-695X.2010.00705.x. PMid:20584079.

MARQUES, C.N.H., DAVIES, D.G. and SAUER, K., 2015. Control of biofilms with the fatty acid signaling molecule cis-2Decenoic acid. Pharmaceuticals, vol. 8, no. 4, pp. 816-835. http:// dx.doi.org/10.3390/ph8040816. PMid:26610524. 
MASLIN, B.R., 1995. Systematics and phytogeography of Australian species of Acacia: An overview. IFA Newsletter, vol. 36 , no. 2 , pp. $2-5$.

PRATIWI, S.U.T., LAGENDIJK, E.L., WEERT, S., IDROES, R., HERTIANI, T. and HONDEL, C.A.M.J.J., 2015. Effect of Cinnamomum burmannii Nees ex Bl. and Massoia aromatica Becc. essential oils on planktonic growth and biofilm formation of Pseudomonas aeruginosa and Staphylococcus aureus in vitro. International Journal of Applied Research in Natural Products, vol. 8 , no. 2 , pp. 1-13.

RIGANO, L., SICILIANO, F., ENRIQUE, R., SENDÍN, L., FILIPPONE, P., TORRES, P.S., QUESTA, J., DOW, J.M., CASTAGNARO, A.P., VOJNOV, A.A. and MARANO, M.R., 2007. Biofilm formation, epiphytic fitness, and canker development in Xanthomonas axonopodis pv. citri. Molecular Plant-Microbe Interactions, vol. 20, no. 10, pp. 1222-1230. http://dx.doi.org/10.1094/MPMI-20-10-1222. PMid:17918624.

SÁNCHEZ, E., RIVAS MORALES, C., CASTILLO, S., LEOSRIVAS, C., GARCÍA-BECERRA, L. and ORTIZ MARTÍNEZ, D.M., 2016. Antibacterial and antibiofilm activity of methanolic plant extracts against nosocomial microorganisms. EvidenceBased Complementary and Alternative Medicine, vol. 2016, pp. 1-19. http://dx.doi.org/10.1155/2016/1572697. PMid:27429633.
SANDASI, M., LEONARD, C.M. and VILJOEN, A.M., 2010. The in vitro antibiofilm activity of selected culinary herbs and medicinal plants against Listeria monocytogenes. Letters in Applied Microbiology, vol. 50, no. 1, pp. 30-35. http://dx.doi. org/10.1111/j.1472-765X.2009.02747.x. PMid:19874481.

SAS INSTITUTE, 2013. The SAS system for Windows. Release 9.4. Cary, NC: SAS Institute.

SHI, L., LI, P., WANG, W., GAO, M., WU, Z., SONG, X. and HU, D., 2015. Antibacterial activity and mechanism of action of sulfone derivatives containing 1,3,4-Oxadiazole moieties on rice bacterial leaf blight. Molecules, vol. 20, no. 7, pp. 11660-11675. http://dx.doi.org/10.3390/molecules200711660. PMid:26114927.

SINGH, A., GUPTA, R., TANDON, S. and PANDEY, R., 2017. Thyme oil reduces biofilm formation and impairs virulence of Xanthomonas oryzae. Frontiers in Microbiology, vol. 8, pp. 1-28. http://dx.doi.org/10.3389/fmicb.2017.01074. PMid:28659894.

SUTHERLAND, I.W., 2001. The biofilm matrix - an immobilized but dynamic microbial environment. Trends in Microbiology, vol. 9, no. 5, pp. 222-227. http://dx.doi.org/10.1016/S0966842X(01)02012-1. PMid:11336839. 